\section{E-LOGOS}

ELECTRONIC JOURNAL FOR PHILOSOPHY

ISSN 1211-0442

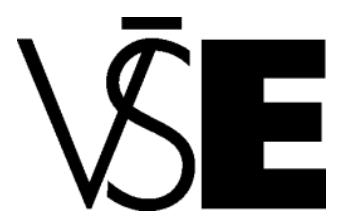

University of Economics

Prague

\title{
Likertovo škálování
}

Aleš Rod

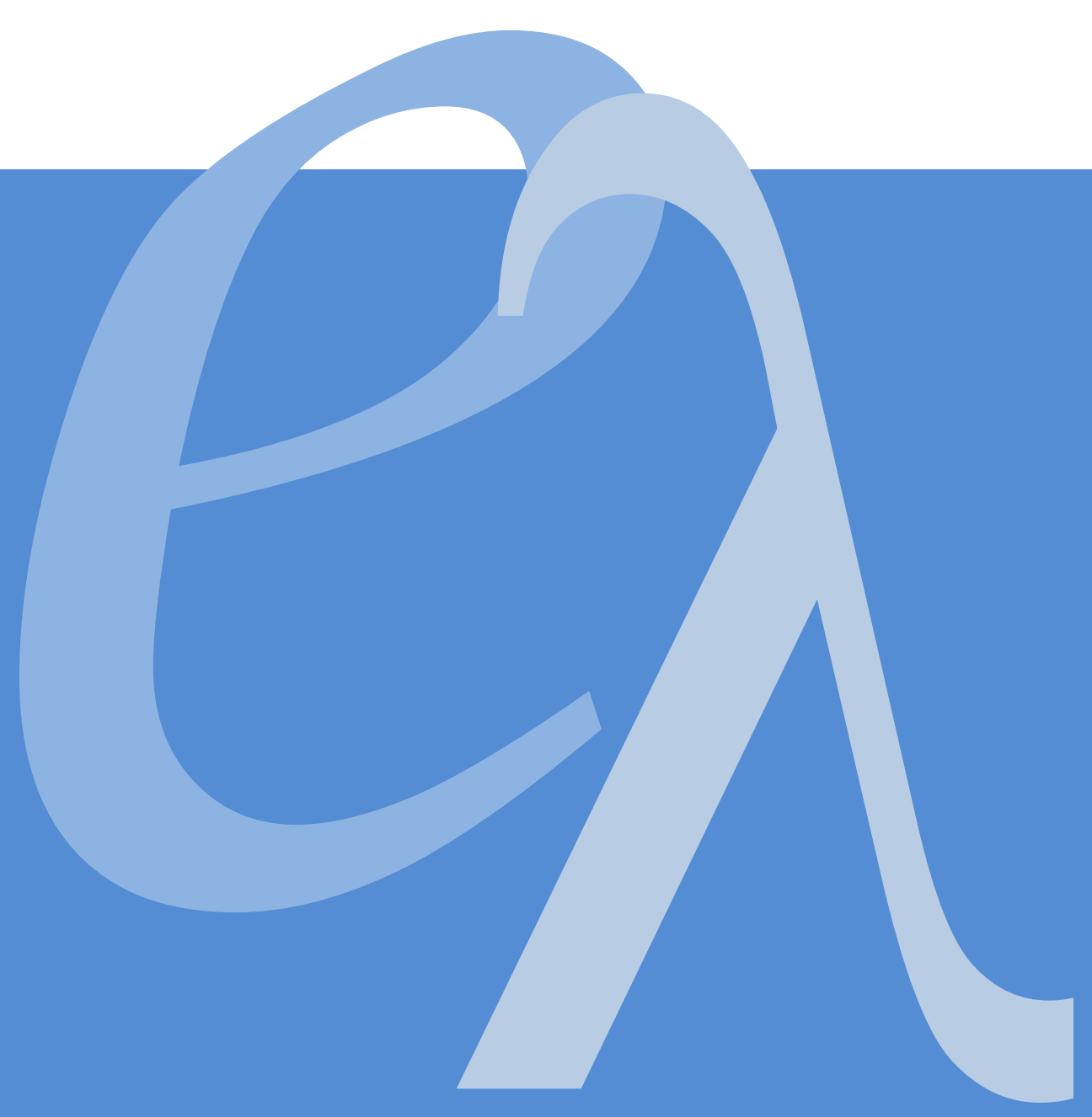




\begin{abstract}
Science and scientific work are in accordance with generally accepted axiom considered as something that generates scientific discoveries, and by that positively moves a human civilization forward. However, a fundamental attribute of wide groups of "phenomenon" creates barriers for scientific discoveries - this attribute is immeasurability. Especially in the social sciences, immeasurability is associated with the absence of hard data, which intensively limits the range of methods that could be applied in the scientific work. Nevertheless, there is a method that aims to eliminate this deficit and, while using the method correctly (i.e. with respect to its general principles), one can quantify the variables seem to be immeasurable at first glance. This method is called scaling.

The text of this paper discusses the approach of methodology and philosophy of science to immeasurable factors and quantifies their potential through onedimensional method called the Likert scaling. The paper is devoted to the description of the method; analyzes its pros and cons, and gives detailed instructions for its application. In conclusion, the answer to the question whether it makes sense for scientists to spend time with learning new methods (such as scaling), while we can say that for scientists, educated in a specific field, studying generates high opportunity cost? To answer this question: we can safely say that studying new methods is not time-wasting, because the opportunity cost is always the cost associated with "the second best option" while having perfect information about alternatives. And, without knowledge about these new methods studied, we can never say that the method we are using is the best one.
\end{abstract}

Keywords: Methodology, method, scaling, one dimensional scaling, Likert scaling, studying of methods, opportunity cost of scientist. 


\begin{abstract}
Abstrakt
Věda a vědecká práce jsou dle obecně přijatého axiomu považovány za něco, co generuje vědecké objevy, a tím pozitivně posouvá lidskou civilizaci směrem dopředu. Vědeckým objevům v určitých oblastech však vytváří bariéry základní vlastnost široké skupiny jevů - neměřitelnost. Zejména ve společenských vědách je neměřitelnost jevu spojena s absencí tzv. tvrdých dat, která omezuje okruh metod, jež by mohly být aplikovány v cestě za vědeckým objevem. Existuje však metoda, která si klade za cíl eliminovat tento deficit a s jejíž pomocí lze, př́i dodržování zásad správného použití, kvantifikovat proměnné, které se zdají být na první pohled neměřitelné. Tato metoda se nazývá škálování.

Text př́ispěvku pojednává o přístupu filozofie a metodologie vědy $\mathrm{k}$ neměřitelným faktorům a jejich potenciální kvantifikaci pomocí jednorozměrné šalovací metody nazvané Likertovo škálování. Stat' paperu se věnuje popisu této metody, analýze jejích kladů a záporů a detailnímu návodu na její aplikaci. V závěru je zodpovězena otázka, zda má pro vědce smysl věnovat čas studiu nových metod (např. právě škálování), když toto pro vědce vzdělaného v určitém oboru generuje velmi vysoké náklady obětované př́ležitosti? Studium nových metod smysl rozhodně má, nebot' obětovaná př́ležitost je dle výkladu středního proudu v ekonomii označována jako „druhá nejlepší varianta“ za podmínky dokonalé informovanosti o dostupných alternativách. Bez uspokojivé znalosti studovaných nových metod však nemůžeme označit doposud aplikovanou metodu za nejvhodnější - to je hlavní argument podporující studium nových metod.
\end{abstract}

Klíčová slova: Metodologie, metoda, škálování, jednorozměrné škálování, Likertovo škálování, studium metod, náklady obětované příležitosti vědce. 


\section{Úvod}

Tím, co posouvá generaci po generaci každou civilizaci dopředu, je dle všeobecně přijatého axiomu věda, a $\mathrm{z}$ úsilí, které v ní generujeme, plynoucí vědecké objevy. Věda jako taková přitom úzce závisí na metodě vědeckého přístupu a názorech na ni. V podání různých autorů se členění věd dle typů a do kategorií může lišit. Normativní, deskriptivní, empirické, modelování, perspektivy, teoretizování... Členění a derivací př́stupů je zkrátka celá řada. Má však jejich studium vůbec smysl?

Všechna jednotlivá pojetí vědy mají společného jmenovatele. Základním atributem "vědeckého" je především eliminace složky náhody - vědec ji dostává do takové podoby, kdy ji může systematicky ř́idit a počítat s ní jakožto s atributem, jehož vliv lze na výstupu specifikovat a odlišit. Je to však možné vždy? A co je vůbec výstup vědy? Definici můžeme zformulovat třeba následovně: vědecký výstup je očekávaným nebo neočekávaným odhalením něčeho na základě systematického výzkumu, které může být pochopitelným způsobem sděleno druhé osobě a které může být vhodnými prostředky ověreno. Pokud např́ílad v přírodě uvidím, že se jedna konkrétní želva nedokáže z pozice "na krunýři“ otočit zpět do přirozené polohy, nelze toto zjištění, jakkoliv je zajímavé, automaticky pokládat za vědecký objev. Co když byl tento jedinec zraněn či jeho přirozená schopnost pohybu byla jinak eliminována? Když však někdo na základě systematického výzkumu pomocí vědeckých metod tento poznatek ověří, na dostatečně velkém vzorku eliminuje složku náhody, nebo ji dokonce dokáže kvantifikovat, lze to brát za vědecké zjištění. K tomuto výsledku se námi uvažovaný vědec mohl dobrat pouze s pomocí aplikace správné metody. Odebral se na cestu za vytouženým výsledkem (metoda: řecky "meta“ = po, nad; + řecky "odos" = cesta $)^{1}$.

V této práci bude popsána vědecká metoda, s níž se autor textu setkal nedávno, ale nikdy ji nepoužil. Přesto jej zaujala. Proč? Protože její definicí je něco, co by mohlo být označeno za protimluv: „prostředek k měření neměřitelného“.

\section{Metodologie a metoda}

Pro analýzu této konkrétní metody je nutné zorientovat se v nauce, která se těmto postupům věnuje - $\mathrm{v}$ metodologii. Následující teoretické vsuvka si klade za cíl odstranit potenciální znalostní deficit, jenž by mohl soužit jako bariéra v pochopení souvislostí.

Metodologií vědy označujeme nauku o metodách, jejímž předmětem je zkoumáni filozofie vědy. Bavíme se tedy o studiu metod a vědeckých postupů, používaných k objevům nových faktů nebo ověřování hypotéz. Metodologie tak vlastně slouží

1 Pstružina, K.: Atlas filozofie vědy, př́stup online, 16. 3. 2012, 17:26, link: http://nb.vse.cz/kfil/win/atlas1/metodol.htm. 
jako klíč. Nelze ovšem říci, že jde o klíč ke konkrétnímu vědeckému poznání, protože tato cesta je mnohem delší a, držíme-li se pojmosloví, skrývá se za větším počtem dveří, než si zpravidla dokážeme představit před zahájením výzkumu. Spíše bychom ji mohli popsat jako klíč do světa, v němž je možné toto bádání vůbec uskutečňovat.

Metodologie je nástrojem, jenž je třeba respektovat a při každém pokusu o vědecký výzkum si osvojit. Bez použití formálně správných postupů vycházejících z definic základních vědeckých metod totiž není možné, a to navzdory sebevětšímu vyvinutému úsilí, podat pravdivé, přesné, vzájemně související a systematické skutečnosti vedoucí k poznání. ${ }^{2} \mathrm{~A}$ o to každému vědci přeci jde. Je pozoruhodné, že lidé někdy postupují ve shodě s metodologií vědy, aniž by věděli, že jsou tyto procesy velmi přesně popsány a vysvětleny, tj. že tyto procesy vycházejí z metodologie vědy a doporučují určitou metodiku vědecké práce (Metodologie vědy $=>$ Metoda vědy => Metoda vědecké práce).

Klasifikace metodologie může být následujííỉ:

- obecná (všeobecná filosofie vědy, obecná východiska vědy, obecně přijaté postupy a argumenty),

- konkrétní (vztahuje se $\mathrm{k}$ danému druhu vědy, např. metodologie přírodních věd, metodologie společenských věd).

Častým omylem vědců bývá víra $v$ to, že existuje univerzální vědecká metoda. Neexistuje. A lze to ř́ci zcela určitě. Specifika postupů, které je nutné uplatňovat v konkrétní vědecké práci, souvisejí vždy se samotným předmětem zkoumání, a ten je partikulární. ${ }^{4}$ Metodu vědce je možné nejlépe charakterizovat jako systematický postup k získávání poznatků a dosažení cíle, který si daný vědec vytyčil, a to $\mathrm{s}$ použitím promyšlené a uspořádané činnosti nebo shluku činností $\mathrm{v}$ daném pořadí, které se soustředí na obsah výzkumu.

Jeho charakteristika může být samozřejmě nekonečná, nicméně vědec má $\mathrm{v}$ podstatě na výběr dva základní intervaly. Za prvé se může pohybovat v prostoru, který lze označit jako pozitivistický. Obsahem tohoto výzkumu je potvrzení reálné existence zkoumaného jevu, nebo jeho vyvrácení. Každopádně jde o konstatování reálného stavu, např́klad že inflace měřená nástrojem $X$ činila v době $t$ 2,3 \% v porovnání se stejným obdobím předchozího roku. Druhým prostorem, v němž je možné se pohybovat, je užití normativního př́stupu. $V$ tom se vědec na základě svých poznatků snaží vytvářet normy, udělovat rady a doporučení. Nezabývá se tedy konstatováním, jaký svět je, ale říká, jaký by měl být. Snaží se udělovat pozitivistickým př́istupům subjektivně vnímanou hodnotu, o které je přesvědčen, že

${ }^{2}$ Ibid.

3 Široký, J.: Publikování výsledků vědy a výzkumu, 2010, Olomouc, str. 15, ISBN 978-80-87240-41-0.

4 Pstružina, K.: Atlas filozofie vědy, př́istup online, 16. 3. 2012, 18:13, link: http://nb.vse.cz/kfil/win/atlas1/metodol.htm. 
je přidanou hodnotou. Tyto hodnotové soudy autora výzkumu mohou představovat velmi podstatné bariéry $\mathrm{v}$ přijímání informace, jelikož velmi záleží na kvalitě prezentace výstupu stejně jako na kritickém myšlení př́ijemců informace.

Jak zaznívá během výuky předmětu Filozofie a metodologie vědy 5 , "metody mohou být specifické, používané jen určitou, nebo určitými vědami; nebo obecné, používané všemi vědami. Mimo to existují $i$ metody čnící si nárok na to být univerzálními. Obecné metody jsou instrumentáriem vědy, a i když se nedospělo jejich zobecňováním $k$ žádné univerzální metodě poznání, je jejich efektionost nesporná. Znalost obecných metod a dodržování všsch pravidel v nich obsažených patří k profesionalitě vèdecké práce."

Vymezení metod se $\mathrm{v}$ pohledech jednotlivých autorů dávajících si za cíl jejich rozdělení různí. Lze však konstatovat, že základní okruh je společný. Například Široký ${ }^{6}$ rozděluje metody podle rozdílného typu vědeckého postupu, a sice na empirické (založeny na zkušenostních principech, které jsou výsledkem již používaných a vyzkoušených postupů bádání prostřednictvím samotného vědce (současnost, minulost) nebo s využitím př́ístrojů), a obecně teoretické metody (nevycházejí primárně z empirických zkušeností či měření, ale jsou všeobecně přijímány jako universální teoretické postupy vědecké práce). Samotné dělení je následující:

- Empirické metody:

○ pozorování

○ měření

○ experiment

- Obecně teoretické metody:
○ analýza
○ syntéza
○ indukce
- dedukce
○ generalizace
- abstrakce
- komparace

\footnotetext{
${ }^{5}$ A stojí i u vysvětlení příslušného termínu zde: Pstružina, K.: Atlas filozofie vědy, př́istup online, 16. 3. 2012, 18:13, link: http://nb.vse.cz/kfil/win/atlas1/metodol.htm.

6 Široký, J.: Publikování výsledků vědy a výzkumu, 2010, Olomouc, str. 15, ISBN 978-80-87240-41-0. (srov. s Pstružina, K.: pozorování, popis a explanace; měření a komparace; experiment; modelování, analýza a syntéza; indukce a dedukce).
} 
○ analogie

O těchto metodách lze najít informace $\mathrm{v}$ celé řadě publikací. $S$ řadou $\mathrm{z}$ nich se lze setkat i během plnění studijních povinností na Vysoké škole ekonomické, a to především při práci s tvrdými daty v rámci jednotlivých předmětů, případně při psaní kvalifikačních prací v bakalářském nebo magisterském stupni studia.

Autor se však v následujícím výkladu zaměří na metodu, s jejíž pomocí by mělo být možné kvantifikovat obtížně měřitelné výroky, a ty posléze zkoumat s využitím běžných statistických, případně ekonometrických nástrojů. Jak již bylo řečeno, touto metodou je Likertovo škálování.

\section{2. Škálování}

Škálování (vytváření škál) můžeme obecně označit jako relativně jednoduchou metodu výzkumu, s pomocí které lze zachytit určitý kvalitativní jev v kvantitativní podobě. Jedná se o transformaci jevu nebo skupiny jevů, které se reálně vyskytují a mají určité vlastnosti, na číselně (nebo jinak) definovanou stupnici, která nám pomůže tento jev změřit, tj. pracovat $s$ ním jako $s$ číselně vyjádřenou proměnou a porovnávat mezi sebou jevy (nebo skupiny jevů) zasazené na jednu vytvořenou škálu. To zcela koresponduje s hojně užívanou definicí Stanleyho S. Stevense, který řekl: „Škálování je prevod objekti̊ na čísla podle určitého pravidla“7.

Snad proto bývá škálování označováno jako prostředek pro „změření nezměřitelného". 8 Používá se zejména ve vědách pracujících s tzv. měkkými daty, jako je např. psychologie nebo sociologie, ale i v ekonomii (vytváření ordinárních čísel pro varianty ekonomického jednání) nebo politologii (zařazení subjektů na pravo-levicovém politickém spektru). Velmi často se užívá v praxi, např. v marketingu (kvantifikace subjektivních dojmů z určitého produktu) nebo HR (zefektivňování procesů na pracovišti).

Ve škálování je stěžejní, aby měl každý level škály smysl. Jedině tak zajistíme, že má každý bod umístěný na škále přidanou hodnotu, na základě které jej můžeme interpretovat, porovnávat nebo s ním jinak vědecky pracovat. Bod umístěný na škále, který nic nepředstavuje, nemá žádnou vypovídací hodnotu a nedoručuje autorovi výzkumu žádnou relevantní informaci. Takový výzkum pak nemá žádný smysl. Je proto důležité, aby ve vytváření škály a v následné realizaci škálovací stupnice platily základní axiomy tranzitivity a úplnosti srovnání.

\footnotetext{
7 Stevens S. S.: Measurement, Psychophysics and Utility, Chap. 2, in C. W. Churchman \& P. Ratoosh (Eds.), Measurement: Definitions and Theories. New York: John Wiley 1959, str. 25.

8 Např. Research Methods Knowledge Base, př́stup online, 17. 6. 2012, 13:52, link: http://www.socialresearchmethods.net/kb/scaling.php
} 
Obecně je možné škálování rozdělit dle několika pohledů. Pravděpodobně nejběžnějším je kategorizace na jednorozměrné (jednodimenzionální) škálování, které bylo vyvinuto v první polovině 20. století a do něhož bývají řazeny následující přístupy:

- Thurstoneovo škálování stejně se jevících intervalů,

- Likertovo (sumační) škálování,

- Gutmannova metoda (kumulativní),

a vícerozměrné (multidimenzionální) škálování, jež bylo poprvé aplikováno v 50 . letech minulého století a během 60 . letech (a následně) postupně zdokonalováno. Tyto pokročilejší techniky umožňují vytváření vícerozměrných systémů. Příkladem takové metody může být konceptové mapování (concept-mapping).

V dalším pohledu, statistickém, se můžeme na škálování dívat jako na rozdělení kardinálních škál (reálná číselná řada), ordinálních neboli pořadových škál (srovnávací - porovnávány objem či intenzita jednoho jevu ve srovnání s druhým jevem, příp. dalšími jevy) či nominálních škál (nejsou posloupností hodnotových soudů, ale varianty hodnoty na škále se vzájemně vylučují).

Ačkoliv je vícerozměrné škálování velmi komplexním nástrojem, pro základní výzkum se jeví metody jednorozměrného škálování jako aplikovatelnější; i autor textu má $\mathrm{k}$ němu blíže. V následující kapitole bude analyzován jediný př́istup Likertovo sumační škálování.

\section{Likertovo škálování}

Likertovo 9 škálování je metodou, která je používána pro určení míry stupně souhlasu či nesouhlasu stvrzením, se kterým jsou respondenti výzkumu konfrontováni. Likertova škála, vyvinuta roku 1932, představuje jednu z nejspolehlivějších technik měření postojů日 ${ }^{10}$. Protože se jedná o jednorozměrnou metodu, měla by být podstata zkoumaného problému zaměřena na jeden předmět. K tomu, aby bylo možné respondenta identifikovat na škále, je nutné nejen vhodným způsobem tuto škálu polarizovat, ale, samozřejmě, i vhodným, nezavádějícím způsobe zformulovat konfrontující tvrzení.

Ačkoli je povětšinou škála vytvářena samotnými autory výzkumu, může být velice užitečné tento krok konzultovat s dalšími osobami, nebot' je tak možné předejít

\footnotetext{
9 Pojmenováno po americkém psychologovi a vědci Rensisu Likertovi.

${ }^{10}$ Hayes, N.: Základy sociální psychologie, překlad: Štěpaníková, I.), Praha, Portál 2003, ISBN 80-7178198-3.
} 
př́lišnému subjektivnímu tlaku na potvrzení vědcovi hypotézy. ${ }^{11}$ Požadavky na vytvoření Likertovy škály jsou obecně chápány poměrně jednoznačně - škála by měla být polarizována od nesouhlasu po souhlas (tedy nikoliv jednostranně), a sice s lichým počtem stupňů.

Tento názor však není možné brát jako dogma. Autor textu se při studiu statistických metod či socio-ekonomické analýze setkal s názory, že lichý počet stupňů na stupnici odpovědí není správný, nebot' vytváří prostor pro vyjádření indiference a následnému zkreslení výsledků, prríp. ovlivnění reality, pokud zainteresované subjekt budou na výsledky výzkumu reagovat. Avšak opačný př́stup, tedy tlak na profilaci a názorovou polarizaci (př́ílon spíše ano, resp. spíše ne) může mít $\mathrm{z}$ vědeckého hlediska také negativní následky - může vést $\mathrm{k}$ plošší distribuci výsledků, která má ovšem menší vypovídací hodnotu, protože nevyjadřuje skutečné přesvědčení respondentů. Je však možné setkat se s tvrzeními, ${ }^{12}$ že absence bodu indiference nemá dopad na výsledky průzkumu, i když připustíme, že u určitých prvků se bude muset respondent přiklonit na jednu nebo druhou stranu, ačkoliv o tom nebude subjektivně přesvědčen. Naproti tomu Dumas tvrdí13, že spolehlivost škály je absencí neutrálního bodu zcela zásadně narušena, čímž pádem je snížena i věrohodnost dosažených výsledků. Závisí tedy pravděpodobně jen na tom, jak se daný vědec v tom kterém výzkumu rozhodne. Znamená to něco?

Ještě složitěǰši než stanovení sudosti/lichosti počtu stupňů je však výběr jednotlivých prvků (bodů, položek, zkrátka podnětů pro hodnotové soudy šetření) v problematice, která je předmětem výzkumu. Zásadním problémem, na který nepanuje jednotný názor, je, zda by měla být stupnice stanovena výhradně autorem výzkumu, a nebo s použitím externího pohledu. Podle autorova názoru je při tomto kroku sestavování škály participace vnějšího elementu nejen vhodná, ale př́mo žádoucí, nap̌r. formou společného brainstormingu, či oponování sestavené skupiny prvků. Podle Trochima ${ }^{14}$ by mělo být $\mathrm{k}$ dané zkoumané problematice dokonce vygenerováno osmdesát až sto položek, z nichž mohou být následně formulována tvrzení v podobě kladného stanoviska (Současná fiskální politika vlády stojí na promyšlené koncepci: Naprosto souhlasím - Spíše souhlasím. - Indiference. - Spíše nesouhlasím. - Naprosto nesouhlasím.), nebo záporného stanoviska (Budova nového nádraží se nehodí do historického centra našeho města: Naprosto souhlasím - Spíše souhlasím. - Indiference. - Spíše nesouhlasím. - Naprosto nesouhlasím.) Vše se odvijí od hypotézy, kterou autor svým výzkumem ověruje. Ale nepředbíhejme...

11 Trochim, William M. The Research Methods Knowledge Base, 2nd Edition, přistup z internetu: http://www.socialresearchmethods.net/kb/.

12 Page-Bucci, H.: The value of Likert scales in measuring attitudes of online learners, př́stup on-line, 23.3.2012, 11:53, link: http://www.hkadesigns.co.uk/websites/msc/reme/likert.htm.

${ }^{13}$ Ibid.

14 Trochim, William M. The Research Methods Knowledge Base, 2nd Edition, přístup online, 23.3.2012, 13:46, link: http://www.socialresearchmethods.net/kb/ 
Při důsledné př́ípravě věrohodné Likertovy škály je totiž zcela zásadní, aby formulace tvrzení vycházela takových bodů, které jsou velmi pečlivě vybrány. Nepoužijeme proto celých sto bodů, ale jen část z nich. Hodnota výsledku výzkumu je na tomto kroku, který je pohříchu velmi často ignorován, naprosto závislá. ${ }^{15}$ Jak by se mělo správně postupovat?

Poté, co je zvoleným přístupem vygenerována dostatečně velká skupina bodů, které je možné použít pro formulaci tvrzení, je nezbytné tyto položky analyzovat utřídit je do několika (např. pěti16) skupin podle vztahu, který zaujímají vzhledem ke zkoumané problematice, jinými slovy je-li vhodné je použít vzhledem k předmětu výzkumu:

- Velmi se neshoduje

- Neshoduje se

- Neutrální

- Shoduje se

- Velmi se shoduje

Tato selekce položek, ze kterých budou vybrány náměty pro tvrzení předkládané respondentům, je důležitá, nebot' s její pomocí můžeme sestavit vyvážený model s vypovídací hodnotou. Na základě této selekce je totiž možné odstranit položky, které se pro daný výzkum nehodí, at' již z důvodu, že nemají přidanou hodnotu, anebo proto, že se mezi nimi vyskytuje př́lišná shoda. V rozhodnutí, které položky ponechat $\mathrm{v}$ modelu, je možné postupovat ${ }^{17} \mathrm{~s}$ pomocí porovnávání párové autokorelace v korelační matici, nebo s pomocí t-testu rozdílů mezi nejlepšími a nejhoršími kvartily souboru. Výsledkem by měl být model s ideálně 10 až 15 položkami, které mají vysokou t-hodnotu ("high discriminators") a shodují se s výzkumným požadavkem.

Na základě vybraných položek (námětů) je vhodné vytvořit soubor tvrzení (oznamovacích vět), v němž se střídají kladná a záporná stanoviska. Tato rozmanitost brání respondentovi upadnout do stereotypu při identifikaci s danou problematikou.

Jak bylo řečeno, existuje několik názorů na to, jaké škálovací stupnice používat, jak na nich volit jednotlivé intervaly a jaké jim přiřazovat hodnoty v kvantifikaci pro vyhodnocení výzkumu (1-7; 1-9; 0-4...). Důležité je vždy si uvědomit, že stupnice má, jakožto prostředek škálovací metody, určitá omezení. Tím nejzákladnějším je, že

$15 \mathrm{~V}$ praxi bývají za Likertovy škály označovány i modely, které systematický výběr prvků pro sestavení konečné podoby dotazníku pro respondenty zcela ignorují.

16 Trochim, William M. The Research Methods Knowledge Base, 2nd Edition, př́stup online, 23.3.2012, 13:46, link: http://www.socialresearchmethods.net/kb/

17 Ibid. 
mnohé hodnotové soudy se snažíme velmi simplifikovat, tj. přiřadit je do intervalů, které však nemusí u rozdílných respondentů odpovídat shodným myšlenkovým pochodům. To vše ovlivňuje rozhodnutí, zda do škály odpovědí zahrnout prostřední (neutrální) hodnotu nebo ne, tj. zda vytvořit jednovrcholovou škálu dvojvrcholovou škálu odpovědí, při které nutíme respondenta $\mathrm{k}$ názorové polarizaci, a také kolik stupňů zvolíme.

Po sestavení modelu jej pak ve zvolené formě (např. dotazníku) předkládáme respondentům, a na základě kvantifikovaných výsledků pak používáme pro ověření hypotéz ${ }^{18}$. Závěrečné skóre se počítá jako součet odpovědí pro každou položku (tvrzení), od toho sumační škálování.

\section{Závěr}

Od jednoho amerického profesora autor textu slyšel následující tvrzení: „Ve světě vědy hrozí riziko, že výzkumnik ustrne při užívání omezeného počtu vědeckých metod, což jej omezuje vzhledem k potenciálnímu poznání, kterého by mohl nabýt s širším rozhledem." Je tomu ale skutečně tak? Opravdu lze tvrdit, že používání jedné, osvojené metody k výzkumu, který má hlavu a patu, $\mathrm{k}$ ověřování hypotéz a $\mathrm{k}$ vytváření přidané hodnoty, je méně, než osvojování si nových metod, nehladě na to, zda budou použity nebo ne? Když se nad tím zamyslíme, nedává to valný smysl. Učení se nových př́stupů má totiž pro vědce se zažitým a vyzkoušeným know-how vysoké oportunitní náklady. Stojí za to podstupovat riziko, vzdávat se dominantní strategie, jen proto, aby se vědec potenciálně dozvěděl, že potenciálně lze zkoumat potenciálně vyvstalou hypotézu s použitím metody XY, kterou předtím nikdy neaplikoval? Má studium nových metod smysl?

Ve stati eseje byla popsána sofistikovaná metoda Likertova škálování, ačkoliv autor textu tuto metodu nikdy v životě nepoužil. Pro výzkum, kterým se zabývá, se tento prýstup prozatím nehodil a výhledově ani nehodit nebude. Proto se $\mathrm{k}$ aplikaci Likertova škálování, jakkoliv se jeví zajímavě, autor nechystá. Byl čas strávený studiem této problematiky vynaložen efektivně?

Ano. Byl. Ačkoliv se k užití konkrétní metody jedinec nechystá, už jen vědomí, že daná metoda existuje, mu zjedné osvojené cesty (methodos) vytváří změt', křižovatku cest, po kterých je možné se vydat. Pokud bychom připustili, že k plnohodnotným a komplexním výsledkům výzkumu postačuje znalost jedné metody, postrádalo by to logiku. Jak totiž rozeznat, jak koho připravovat a koho kterou metodu vyučovat? Existovaly by vůbec dnešní metody bez staletí poznání, vyplněných úspěšnými výzkumy, stejně jako neúspěchy, pokusy a omyly? Nikoliv. Oportunitní náklady totiž vyjadřují náklady obětované příležitosti, která je, jak

${ }^{18}$ Nebo jejich stanovení pro další výzkum. 
známo, druhou nejlepší možnou alternativou. U vstřebávání poznání, v tomto případě ve formě studia vědecké metody, je autor dalek označovat tuto aktivitu jako „druhou“ nejlepší aktivitu. Protože bez dostatečných znalostí oné metody jako předmětu studia nemůžeme odpovědět na otázku, zda pro vědce nebude v budoucnu nejlepší možná metoda. Nebo dokonce jediná možná metoda! Bez znalosti bychom si tak odpírali klíč k otevírání dveří, za nimiž se poznání nachází. 


\section{Bibliografie}

Hayes, N.: Základy sociální psychologie; (překl. Štěpaníková, I.), Praha: Portál. ISBN 80-7178-198-3.

Page-Bucci, H.: The value of Likert scales in measuring attitudes of online learners, př́stup on-line, 23.3.2012, 11:53, link:

http://www.hkadesigns.co.uk/websites/msc/reme/likert.htm

Pstružina, K.: Atlas filozofie vědy, prrístup online, 16.3.2012, 17:26, link: http://nb.vse.cz/kfil/win/atlas1/metodol.htm.

Research Methods Knowledge Base, př́stup online, 17.6.2012, 13:52, link: http://www.socialresearchmethods.net/kb/scaling.php

Stevens S. S.: Measurement, Psychophysics and Utility, Chap. 2, in C. W. Churchman \& P. Ratoosh (Eds.), Measurement: Definitions and Theories. New York: John Wiley 1959, str. 25.

Široký, J.: Publikování výsledků vědy a výzkumu, 2010, Olomouc, str. 15, ISBN 978-80-87240-41-0.

Trochim, William M. The Research Methods Knowledge Base, 2nd Edition, př́stup z internetu: http://www.socialresearchmethods.net/kb/. 


\section{E-LOGOS}

\section{ELECTRONIC JOURNAL FOR PHILOSOPHY}

Ročník/Year: 2012 (vychází průběžně/ published continuously)

Místo vydání/Place of edition: Praha

ISSN 1211-0442

Vydává/Publisher:

Vysoká škola ekonomická v Praze / University of Economics, Prague

nám. W. Churchilla 4

Czech Republic

13067 Praha 3

IČ: 61384399

Web: http:/ / e-logos.vse.cz

Redakce a technické informace/Editorial staff and technical information:

Miroslav Vacura

vacuram@vse.cz

Redakční rada/Board of editors:

Ladislav Benyovszky (FHS UK Praha, Czech Republic)

Ivan Blecha (FF UP Olomouc, Czech Republic)

Martin Hemelík (VŠP Jihlava, Czech Republic)

Angelo Marocco (Pontifical Athenaeum Regina Apostolorum, Rome, Italy)

Jozef Kelemen (FPF SU Opava, Czech Republic)

Daniel Kroupa (ZU Plzeň, Czech Republic)

Vladimír Kvasnička (FIIT STU Bratislava, Slovak Republic)

Jaroslav Novotný (FHS UK Praha, Czech Republic)

Jakub Novotný (VŠP Jihlava, Czech Republic)

Ján Pavlík (editor-in-chief) (VŠE Praha, Czech Republic)

Karel Pstružina (VŠE Praha, Czech Republic)

Miroslav Vacura (executive editor) (VŠEE Praha, Czech Republic) 